\title{
Factors Influencing Students' Motivation to Seek Higher Education-A Case Study at a State University in the Czech Republic
}

\author{
Adéla Fajčíková *(i) and Hana Urbancová(i) \\ Department of Management, Faculty of Economics and Management, Czech University of Life Sciences Prague, \\ Kamýcká 129, Suchdol, 16500 Prague, Czech Republic \\ * Correspondence: fajcikova@pef.czu.cz
}

Received: 16 June 2019; Accepted: 27 August 2019; Published: 29 August 2019

check for updates

\begin{abstract}
The quality of universities in the present era is the subject of ever more discussion in the Czech Republic and the EU. Quality is determined both quantitatively and qualitatively, and ever more importance is placed on ratings by students and graduates. The objective of this article is to identify and evaluate factors influencing the motivation of students to seek higher education and their expectations regarding the quality of a university. The data was obtained using questionnaire-based investigation among the students of a state university $(n=293)$ and was analysed using descriptive and multivariate statistics. The results identified seven factors that influence the motivation and expectations of students, of which the most significant are quality personnel providing instruction, building social status, development of competencies, and the quality of the education process in relation to employment. The recommendations presented can help other universities to implement suitable personnel marketing and to gain sustainable competitive advantage.
\end{abstract}

Keywords: higher education; marketing activities; motivation; quality assurance; students' satisfaction; sustainability; Czech Republic

\section{Introduction}

Higher education is currently perceived as highly competitive, dynamic, and global [1-4]. It is influenced by global trends and not uncommonly by changes of an economic and social character. For this reason, an even greater emphasis is placed on quality assurance of the educational process of institutions of higher education and their sustainability, which is a common goal not only of governments, university management and faculty but of all groups immediately involved $[5,6]$. The theme presented is currently highly topical, given the growing world-wide emphasis on the quality of university education, according to the global accreditation organisation Accreditation Council for Business Schools and Programs (ACBSP) and its focus on cross-disciplinary, scholarly, social sustainability of human, in this case university students.

Despite the ongoing discussions and results of previous studies, there is no universal guide for broadly assessing the quality of higher education [7]. The reason is mostly the fact that quality in the university environment is complex, multifunctional, and difficult to define [8]. For this reason, the university environment is seeing the greater application of the tools of Total Quality Management, which is a system of continuous improvement of services offered to customers [9]. Managing relationships with customers who are students, in the case of higher education, is fundamentally impacted by the competitiveness of the institution and its ability to respond flexibly to changes in the needs and expectations of students from the education process [10]. Another authors agree, and state that only an approach based on the active engagement of students in the creation of 
university education will enable their full satisfaction [11]. However, in connection with attracting customers (students), also emphasize the ever-increasing importance of marketing communication where interactive marketing communication tools mediated by the students' decision-making process have a major impact on the brand and image of the educational institution [4].

Institutions of higher education and the individual faculties themselves are measured in the current competitive environment using official rankings published by a wide range of agencies and organisations that measure their global competitiveness and sustainability [12]. The management of the institutions presumes that successful placement in these rankings will help build the good reputation of the educational institution and attract new students and retain the existing ones because students can use these criteria when choosing an educational institution $[13,14]$. Placement in the rankings is considered a very useful comparative tool for institutions of higher education throughout the world, and heavily promotes the university, which helps attract not only high-quality students but also the academic staff [15]. There are several methodologies to compare the quality of institutions of higher education, such as the frequently cited Times Higher Education (THE) World University Rankings. This international ranking of scientific, research and development activities also evaluates education, collaboration with the outside world, and international scale of the institution. Specifically, the THE rankings are based on the following composite categories and weightings: training and instruction, research, citations, international scale, and revenues on scientific and creative activities from private sources. However, some scholars point out grave defects of performance criteria that perceive an educational institution as a whole and do not take into consideration the individual fields of study or research and also do not consider institutional characteristics such as the size or age of the institution [15]. Educational institutions in various countries also operate under differing political and socioeconomic conditions, and thereby face differing societal demands [16]. The performance criteria used in the global ranking are therefore not necessarily in accordance with the individual goals of the institution.

On the other hand, Ďurišová et al. consider the quality of educational institutions from the perspective of assessing the results of instruction, which are reflected in the progress of students in teaching, skills, and attitudes [17]. Other authors prioritize an approach to evaluating the quality of colleges and universities based on satisfying the needs and expectations of students as the primary customers of educational institutions $[18,19]$.

It can be said that the quality of educational institutions can be evaluated in various ways, quantitatively (e.g., traditional assessment of student and graduate results, total number of students and graduates relative to students accepted, etc.) or qualitatively using the employability of students in practice or assessment of subjective student satisfaction $[20,21]$. In the current stage of social development, a transition is taking place from quantitative to qualitative assessment of results [17] and students' satisfaction represents a key output variable for providing their services [22]. The results of recent studies prove that student satisfaction is an important tool of the relationship marketing and currently a fundamental tool of the personnel marketing of colleges and universities $[11,20]$. Educational institutions wishing to succeed in the specific conditions of a given country or at an international level must determine and evaluate the motivation, expectations, and needs of their students $[19,21]$. It can be said that the higher education environment has undergone significant changes in previous years. The education market has become ever more competitive due to the increased numbers of educational institutions [23], as well as other educational institutions outside the classic system of education. The rise of the Internet and the development of technologies has also brought significant changes to the methods by which students obtain their knowledge, information, and experience, as well as the demands for knowledge and skills among graduates [11,24]. Employers above all favour graduates with developed general competencies who are willing and able to continue their education, students with international experience, and students with established work habits [25]. Based on the abovementioned information and other research findings the following facts can be summarized $[19,26,27]$ : 
- Students have different expectations from the educational institution and their reasons to pursue university studies vary.

- Students' characteristics can influence the reason for choosing an educational institution.

- Students perceive the quality of teaching differently and consider different criteria for selecting a concrete university.

- The choice of communication channels and marketing tools of an educational institution affects its ability to attract and to retain students.

- Students are motivated for further studies by different stimuli that may be related to the teaching environment, the subject taught, the way of teaching and the teacher's personality.

It can be said that the purpose of each higher education institution is to satisfy the needs of its students, to meet their expectations and to provide high-quality education services that enable students to gain a competitive advantage in the labour market. However, with today's highly competitive pressure, educational institutions must be able to build an institution's brand and choose such marketing tools that will convince all stakeholders of its qualities [28,29]. Only by recognising the different needs, preferences, motivation, wishes and other characteristics of students, a higher education institution can respond to these differences, gain a sustainable competitive advantage among educational institutions, and create effective concepts and strategies to attract and retain students or to constantly improve the quality of its services. This knowledge can then be used by higher education institutions to formulate policies and target at specific groups of students to ensure a favourable academic environment and increase their image.

The objective of this article is to identify and evaluate factors influencing the motivation of students to pursue higher education and their expectations regarding the quality of a college or university. A separate goal is to identify the reasons motivating students to study at a specific university in the Czech Republic and based on the findings to propose to the institutions, or to other educational institutions of similar specialization, modifications of their activities to improve their relationships with students.

The article presents a summary of the current knowledge in Theoretical Background, from which the basic research questions and hypotheses resulted, then it describes the used research methods and statistical techniques in Materials and Methods, afterwards the gathered findings are assessed in Results, the achieved and presented results are then compared with those of international studies in Discussion and, finally, recommendations to the institution under examination are given in Results.

The article evaluates data from the Faculty of Economics, whose research has been approved by the management of the university, and results of which will be used to develop marketing communication with potential students, see Materials and Methods.

\section{Materials and Methods}

An online quantitative survey among students of the selected university was used to obtain primary data. The survey focused on all first-year students in the bachelor's study program at a state university (the selected faculty with an economic specialization) in the Czech Republic who began their university studies in the $2017 / 2018$ academic year $(N=1423)$. The sample of first-year students was authorised by the dean of the faculty because first-year students can bring new information about the factors influencing students' motivation to study at the university. Based on the results the faculty can change its approach to students' motivation and increase the efficiency of its marketing communication with potential students. The survey was distributed to all students electronically on behalf of the study department with the dean's permission. Each of the respondents obtained an automatic email invitation to participate in the given study in November 2017 with a follow-up request for involvement in the study 14 days later. A total of $n=293$ students participated in the survey (response rate $=20.6 \%$ ). The selection sample size was defined using the Krejcie and Morgan (1970) formula ( $N=1423$, required confidence level at $95 \%$ (standard value of 1.96), the acceptable deviation rate $\mathrm{d}=0.03$ and the expected 
deviation rate $r=0.04$ ). Using this statistical approach to sample size computation and based on the above-mentioned rates, the minimum number of respondents was set at 148, which requirement was met by the conducted survey $(n=293)$. The questionnaire respected the ethical perspective and anonymity of the respondents.

The questionnaire consisted of 10 questions, a total of four identification, two closed questions with the option for one answer and four summary study questions composed of claims (the option to express the level of agreement with the individual claims on a five-point scale - strongly agree, agree, neutral, disagree, and strongly disagree). For the needs of this article, respondent replies were merged into the options yes (strongly agree, agree) and no (neutral, disagree, and strongly disagree). The questionnaire is enclosed with the article.

Basic information about the sample of respondents:

- $\quad$ Gender: female $(174,59.4 \%)$, male $(119,40.6 \%)$

- Age category: $18-20$ years old (206, 70.3\%), 21-23 years old (64, 21.8\%), more than 24 years old $(23,7.8 \%)$

- Type of secondary school attended: technical/vocational school (102, 34.8\%), preparatory school/lyceum $(90,30.7 \%)$, business academy $(101,34.5 \%)$.

In the first part of the study, the results were subjected to multivariate statistics using factor analysis according to the recommendation of Anderson [30]. The objective of the analysis was to determine what factors influence the motivation of students to seek higher education and what expectations students have from a college or university in terms of quality assurance of instruction.

For the evaluation of results, properties of the observed conduct of respondents must be studied (the reasons for carrying on with university studies, criteria for selecting the university, the factors influencing students' approach to their studies) that were replaced with a smaller number of other (albeit artificially formed) variables summarising the facts learned about the fundamental variables. Newly developed factors are designed to simplify the overall number of results and explain the variability and interdependences of the variables considered. A factor analysis was used to develop factors that sum up preferences and place them in comprehensive groups. This means that the factor analysis employed in the contribution studies and evaluates mutual linear relations between the variables observed, which are perceived by the factor analysis as the result of the existence of directly unmeasurable known or hypothetical general influences. It must be noted that, in the case of the factor analysis, the approach is more heuristic, requiring a profound understanding of the issue at hand, but also extensive knowledge and experience with the selected method of analysis for the correct interpretation of results. That is why the method is rejected by certain statisticians as insufficiently exact, insufficiently conclusive, and subjective. Many researchers in the field of social sciences (e.g., sociologists) and in human resource and human conduct research use factor analyses frequently and trust it very much [30].

Factor analysis was based on a correlation matrix. Before the application of factor analysis, the correlation matrix was created and subjected to further analysis and interpreted with a view to the suitability of further calculations using multidimensional methods.

To select the substantial factors, the Varimax method and the Kaiser-Guttman rule were used in the factor analysis (after correlation analysis and principal component analysis). Data was processed only if the value of substantial factors was greater than 1 and values exceeding 0.3 were considered to be statistically significant, which is the minimum value used primarily in social research based on the preferences of individual research participants [30].

The second part of the analysis focused on the reasons for studying at a specific college or university. The results of the identified criteria based on literature review were subjected to the statistical analysis using tests of dependence ( $\chi 2$ test) and powers of dependence (Cramer's V). It can be summarised that if the calculated $p$-value was below the significance threshold $\alpha=0.05$, the null hypothesis was rejected; after that, the strength of the correlation was determined using Cramer's V. 
The results of the strength of the correlation were interpreted in accordance with the categories in [30]. As part of the analysis, the following statistical null hypotheses were tested:

- $\mathrm{H}_{0} 1$ : There is no statistical dependency between the predominant reasons of students to study at the selected university and gender.

- $\mathrm{H}_{0}$ 2: There is no statistical dependency between the predominant reasons of students to study at the selected university and age category.

- $\mathrm{H}_{0} 3$ : There is no statistical dependency between the predominant reasons of students to study at the selected university and the type of secondary school attended.

To test for dependencies, the answers of the respondents were merged into the responses yes, neutral, and no. IBM SPSS Statistics statistical software (IBM Corporation, Armonk, NY, USA) was used to test the results. A reliability test was carried out within the framework of statistical testing, using the Cronbach's Alpha coefficient. The level of variable coexistence was calculated with the SPSS programme at 0.829 , which can be considered a high level and the test can hence be considered reliable. The type of the article is a case study. We can summarise that a case study was used as a qualitative method which allowed a detailed study of one case in order to apply the obtained findings to understand similar cases [30]. Case study research refers to an in-depth, detailed study of an individual or a small group of individuals, in this case at one economic faculty ( $\mathrm{n}=293$ respondents). Such studies are typically qualitative in nature, resulting in a narrative description of behaviour or experience. It must be stated that case study research is not used to determine cause and effect, nor is it used to discover generalizable truths or make predictions; rather, the emphasis in case study research is placed on exploration and description of a phenomenon.

\section{Results}

\subsection{Motivation and Expectation of Students}

During the research carried out, respondents were asked about the reasons that led them to apply for university, the factors influencing the choice of a university from a broad range of educational institutions available, and about the factors that have an impact on their approach to their studies (respondents were permitted to check off several responses). The specific results are shown in Tables 1-3.

Table 1. Reasons to pursue university studies.

\begin{tabular}{ccc}
\hline Variable & Absolute Frequencies & Relative Frequencies \\
\hline Extending student life & 179 & 61.1 \\
Education expectations from the family, friends and colleagues & 194 & 66.2 \\
Gaining a good social status & 229 & 78.2 \\
Possibility of earning more money in the future & 260 & 88.7 \\
Desire to continue studying & 210 & 71.7 \\
Obtaining a university degree & 251 & 85.7 \\
Possibility of getting a dream job & 184 & 62.8 \\
Better career growth prospects & 254 & 86.7 \\
\hline
\end{tabular}

Table 2. Factors having an impact on the choice of university.

\begin{tabular}{ccc}
\hline Variable & Absolute Frequencies & Relative Frequencies \\
\hline Finding a good job after graduation & 202 & 68.9 \\
Quality of teaching & 191 & 65.2 \\
Financial demands of study & 181 & 61.8 \\
Chances of successful graduation & 230 & 78.5 \\
Accessibility of education & 180 & 61.4 \\
Plexibility of education according to individual needs & 124 & 42.3 \\
Possibility of studying in a foreign language/abroad & 77 & 26.3 \\
Specialization of the university & 172 & 58.7 \\
\hline
\end{tabular}


Table 3. Factors having an impact on students' approach to their studies.

\begin{tabular}{ccc}
\hline Variable & Absolute Frequencies & Relative Frequencies \\
\hline Personality of the teacher & 132 & 45.1 \\
Interactive teaching & 117 & 39.9 \\
Open discussion, teamwork & 120 & 41.0 \\
Modern teaching methods & 184 & 62.8 \\
Professional competences of the teachers & 164 & 56.0 \\
Combining theory and practice & 179 & 61.1 \\
Difficult tasks that pose a challenge & 67 & 22.9 \\
Positive and supportive environment & 198 & 67.6 \\
Desire to learn and develop & 195 & 66.6 \\
Financial reward (merit scholarship) & 72 & 24.6 \\
\hline
\end{tabular}

For a more detailed analysis of the results discovered, the variables were then subjected to a factor analysis for the purposes of which they were combined under the single title Motivational factors.

According to the frequency of positive responses (agree and strongly agree) with the individual claims in relative expression, the responses of the students may be summarised as follows:

- The main reasons for studying at the university included the possibility of earning more money in the future $(88.7 \%)$, better career growth prospects $(86.7 \%)$ and obtaining a university degree $(85.7 \%)$.

- When selecting a university, students considered primarily the criteria of chances of successful graduation (78.8\%), finding a good job after graduation (68.9\%), and quality of teaching $(65.2 \%)$.

- The main variable with a positive effect on the students' approach to their studies includes positive and supportive environment $(67.6 \%)$, desire to learn and develop $(66.6 \%)$, modern teaching methods $(62.8 \%)$, and combining theory and practice $(61.1 \%)$.

The data obtained as part of the qualitative study was subjected to factor analysis, where the factors most influencing the motivation of students to seek higher education and their expectations of the quality of higher education were identified. As part of a complex evaluation of the factors, 7 significant factors that altogether explain $61.836 \%$ of the behaviour of the examined sample were identified. The individual factors and their significance are listed in Table 4.

Table 4. Variance explained by factors - motivational factors.

\begin{tabular}{cccc}
\hline Factor & Total Variance & Total $\%$ of Variance & Cumulative $\%$ of Variance \\
\hline 1 & 7.168 & 27.568 & 27.568 \\
2 & 2.355 & 9.057 & 36.625 \\
3 & 1.949 & 7.497 & 44.123 \\
4 & 1.326 & 5.101 & 49.223 \\
5 & 1.198 & 4.607 & 53.831 \\
6 & 1.059 & 4.072 & 57.903 \\
7 & 1.023 & 3.934 & 61.836 \\
\hline
\end{tabular}

Factor 1 had the greatest effect, covering almost $28 \%$ of the individual variables. Detailed results of the factor analysis influencing the motivation of students to seek higher education are listed in Table 5. All factors with a value greater than 0.3 are statistically significant with a view to their field focus [30].

Based on the results of the factor analysis, it could be seen that a significant group of students in the selected sample focuses on high-quality personnel providing instruction (factor 1) when selecting a college or university and assessing its quality. For this reason, students positively rate interactive teaching and alternating individual and group work, open discussion and teamwork, modern teaching methods, the personality of the teacher, combining theory and practice, positive and supportive environment. In sum, these students expect training and transfer of practically applicable knowledge 
and skills from experts who support options for effective communication and learning from experience. The second factor covers the group of students in the selected sample who emphasize building social status and continual career building. This is more or less a materialistic approach, where preference is given to the possibility of earning more money in the future, better career growth prospects, gaining a good social status, possibility of getting a dream job, obtaining a university degree. These students consider higher education to be a means toward future success.

Table 5. Resultant factors by the Varimax method - motivational factors.

\begin{tabular}{|c|c|c|c|c|c|c|c|}
\hline \multirow[b]{2}{*}{ Variable } & \multicolumn{7}{|c|}{ Factor } \\
\hline & 1 & 2 & 3 & 4 & 5 & 6 & 7 \\
\hline Extending student life & -0.009 & -0.013 & -0.038 & 0.112 & -0.016 & 0.744 & 0.285 \\
\hline $\begin{array}{l}\text { Education expectations from the family, friends } \\
\text { and colleagues }\end{array}$ & 0.031 & 0.134 & -0.162 & -0.025 & 0.176 & 0.739 & -0.071 \\
\hline Gaining a good social status & 0.170 & 0.752 & -0.013 & 0.106 & 0.049 & 0.213 & -0.055 \\
\hline Possibility of earning more money in the future & 0.053 & 0.820 & 0.024 & 0.200 & 0.110 & 0.003 & -0.034 \\
\hline Desire to continue studying & 0.122 & 0.165 & 0.653 & 0.208 & -0.069 & -0.197 & 0.311 \\
\hline Obtaining a university degree & -0.059 & 0.640 & 0.195 & 0.019 & 0.043 & 0.255 & 0.051 \\
\hline Possibility of getting a dream job & 0.200 & 0.685 & 0.173 & 0.188 & 0.048 & -0.162 & 0.217 \\
\hline Better career growth prospects & 0.128 & 0.779 & 0.152 & 0.054 & 0.089 & -0.155 & 0.214 \\
\hline Finding a good job after graduation & 0.286 & 0.311 & 0.120 & 0.713 & -0.031 & 0.072 & 0.031 \\
\hline Quality of teaching & 0.347 & 0.242 & 0.221 & 0.646 & 0.131 & -0.051 & -0.055 \\
\hline Financial demands of study & 0.163 & 0.082 & -0.054 & 0.326 & 0.632 & -0.099 & 0.096 \\
\hline Chances of successful graduation & -0.008 & 0.043 & 0.150 & -0.163 & 0.730 & 0.223 & -0.063 \\
\hline $\begin{array}{l}\text { Flexibility of education according to } \\
\text { individual needs }\end{array}$ & 0.121 & 0.126 & 0.024 & -0.013 & 0.719 & -0.003 & -0.004 \\
\hline Accessibility of education & 0.048 & 0.000 & -0.012 & 0.462 & 0.494 & 0.137 & 0.177 \\
\hline $\begin{array}{l}\text { Possibility of studying in a foreign } \\
\text { language/abroad }\end{array}$ & 0.221 & 0.139 & 0.138 & 0.087 & 0.023 & 0.168 & 0.672 \\
\hline Specialization of the university & 0.128 & 0.136 & 0.296 & 0.558 & -0.013 & 0.039 & 0.369 \\
\hline Personality of the teacher & 0.704 & 0.000 & 0.137 & 0.091 & 0.177 & 0.095 & 0.171 \\
\hline Interactive teaching & 0.784 & 0.116 & 0.047 & 0.061 & 0.152 & -0.055 & 0.308 \\
\hline Open discussion, teamwork & 0.739 & 0.135 & -0.011 & 0.078 & 0.042 & -0.107 & 0.245 \\
\hline Modern teaching methods & 0.715 & 0.083 & 0.230 & 0.226 & -0.013 & 0.002 & -0.028 \\
\hline Professional competences of the teachers & 0.507 & 0.024 & 0.548 & 0.174 & 0.075 & -0.036 & -0.225 \\
\hline Combining theory and practice & 0.601 & 0.058 & 0.420 & 0.224 & 0.026 & 0.105 & -0.212 \\
\hline Difficult tasks that pose a challenge & 0.308 & 0.080 & 0.595 & -0.072 & 0.145 & 0.002 & 0.219 \\
\hline Positive and supportive environment & 0.585 & 0.254 & 0.377 & 0.189 & 0.049 & 0.073 & -0.029 \\
\hline Desire to learn and develop & 0.139 & 0.194 & 0.748 & 0.190 & 0.035 & -0.121 & 0.043 \\
\hline Financial reward (merit scholarship) & 0.217 & 0.156 & 0.231 & 0.252 & 0.245 & 0.126 & 0.346 \\
\hline Total \% of Variance & 27.568 & 9.057 & 7.497 & 5.101 & 4.607 & 4.072 & 3.934 \\
\hline
\end{tabular}

The bold variables in one column describe behaviour of a group of students.

Factor 3 covers a group of students in the selected sample who seek to develop competencies and implement them organically in practice. Students focused on competency development are distinguished by a desire to seek further education and thereby develop their present capabilities and skills; they prioritize difficult tasks that pose a challenge and expect the transfer of theoretical and practical knowledge from qualified experts. Another group (factor 4) consisted of students in the selected sample who primarily emphasize the quality of the education process in relation to employment (finding a good job after graduation, quality of teaching and specialisation of the university). Certain students focused primarily on advantageousness of the institution of higher education (factor 5 - externality), where they consider its financial demand, the likelihood of completing studies, options for adapting instruction to their personal needs, or transportation accessibility. The least significant factors were grouped together in factor 6, which combines undecided students looking for extending student life and fulfilling the expectations of their community and factor 7 , typically for students looking only for the international experience. 


\subsection{Reasons for Studying at the Selected University}

Given the general specification of factors influencing the motivation of students to seek higher education and their expectations (see Table 5), the results were subjected to further testing focused on specific reasons for studying at the selected institution.

Most of the respondents stated that they learned about the educational institution (the selected faculty) from relatives or acquaintances $(195,66.6 \%)$ and the internet $(167,57.0 \%)$. To a substantially lesser extent, students learned about the faculty from educational expositions $(49,16.7 \%)$, open campus days $(41,14.0 \%)$, or directly from teachers at their secondary schools $(39,13.3 \%)$. Only 9 respondents stated that they learned about the faculty via presentation of the university or faculty in their school. Most of the students (191, 65.2\%) planned to work in their field of study; 15 (5.1\%) planned to work in a different field, and almost a third $(87,29.7 \%)$ were not certain of their plans at that time.

The data was subjected to the descriptive statistics, and the statistical hypotheses were tested in accordance with the methodology of the article. The results of dependency testing are listed in Table 6 .

Table 6. Reasons to study at the selected university.

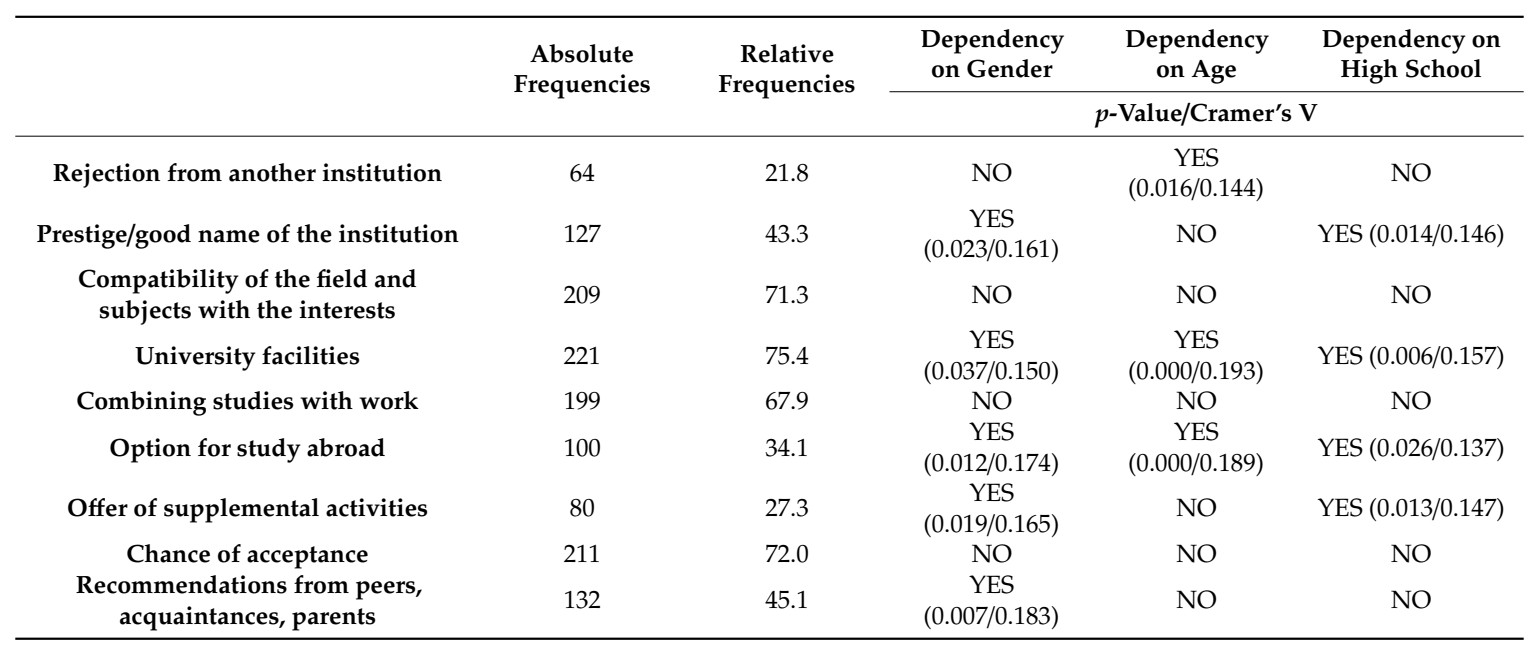

The most frequent reasons why respondents decided to begin their higher education at the selected university include university facilities (campus, classrooms, etc.) (75.4\%), the chance of acceptance $(72 \%)$, and compatibility of field and subjects of study with the interests of the student $(71.3 \%)$. More than half $(67.9 \%)$ of the students also value the option to combine their studies with work.

Results indicate that in all cases for which a statistical dependency was demonstrated with regard to gender, women ranked their reasons for beginning their higher education at the given faculty more positively than men did. The reasons for studying at the given faculty also differed depending on the age of the respondents. Whereas the facilities of the university were on average the primary attractor of the university (75.4\%), it was important only for $43.5 \%$ of students over the age of 24 years. The importance of the availability of study abroad also decreased with age (by age group from the youngest to the oldest: $38.8 \%, 29.7 \%$, and $4.3 \%$ ). It may be concluded that older students do not plan to spend time on campus or to negotiate international study trips to the same extent as younger students. Similar results were discovered with reasons for rejection from other colleges and universities, where the importance of criteria decreased with age.

The test also demonstrated statistical significance with the identification variable of the type of secondary school attended. In the case of an option to study abroad and offer of supplemental activities, which generally rank among the least significant reasons for beginning higher education at a given faculty, an average of $20 \%$ higher negative attitudes were discovered for graduates from technical secondary schools than for graduates from preparatory schools and business academies. There is also a $20 \%$ difference between the ratings of preparatory schools and business academies (in total 
$82.2 \%)$ and secondary technical schools $(62.7 \%)$ for a positive rating of the criterion of university facilities. The last statistically significant dependency was determined for evaluating the prestige of the institution. By secondary school attended, this criterion is most significant for graduates from business academies, then preparatory schools, and lastly for graduates from technical secondary schools.

In accordance with the methodology of the article and the results of the testing conducted, it can be summarised that:

- There is a statistical dependency between the predominant reasons of students to study at the selected university and gender (strength of dependency from $0.150-0.183$ ).

- There is a statistical dependency between the predominant reasons of students to study at the selected university and age category (strength of dependency from 0.144-0.193).

- There is a statistical dependency between the predominant reasons of students to study at the selected university and type of secondary school attended (strength of dependency from 0.137-0.157).

The data obtained was once again subjected to the multivariate statistics using the factor analysis to better understand the overarching reasons why students had enrolled in the selected college (see Table 7).

Table 7. Variance explained by factors - reasons to study at the selected university.

\begin{tabular}{cccc}
\hline Factor & Total Variance & Total \% of Variance & Cumulative \% of Variance \\
\hline 1 & 2.676 & 29.737 & 29.737 \\
2 & 1.421 & 15.786 & 45.523 \\
3 & 1.037 & 11.517 & 57.039 \\
4 & 1.020 & 11.334 & 68.374 \\
\hline
\end{tabular}

From the factor analyses performed, 4 significant factors emerged combining the analysed variables. The first factor has a strength of approx. $30 \%$, the second approx. $16 \%$, the third $11.5 \%$, and the fourth $11.3 \%$. The first factor can be considered crucial as part of the reasons why students began their higher education at the selected university or faculty. Table 8 details the results of the factor analyses.

Table 8. Resultant factors by the Varimax method - reasons to study at the selected university.

\begin{tabular}{ccccc}
\hline Variable & Factor $\mathbf{1}$ & Factor $\mathbf{2}$ & Factor 3 & Factor $\mathbf{4}$ \\
\hline Rejection from another institution & 0.285 & -0.328 & 0.236 & -0.689 \\
Prestige/good name of the institution & 0.308 & $\mathbf{0 . 7 1 5}$ & 0.032 & 0.094 \\
Compatibility of the field and subjects & 0.113 & $\mathbf{0 . 6 5 6}$ & -0.063 & -0.045 \\
with the interests & $\mathbf{0 . 6 5 1}$ & 0.350 & 0.007 & 0.111 \\
University facilities & 0.355 & -0.213 & 0.185 & $\mathbf{0 . 7 6 5}$ \\
Combining studies with work & $\mathbf{0 . 8 5 8}$ & 0.060 & 0.099 & -0.017 \\
Option for study abroad & $\mathbf{0 . 8 5 7}$ & 0.167 & 0.101 & 0.010 \\
Offer of supplemental activities & 0.128 & -0.244 & $\mathbf{0 . 8 0 5}$ & -0.062 \\
Chance of acceptance & 0.031 & $\mathbf{0 . 5 0 3}$ & 0.710 & 0.089 \\
Recommendations from peers, & $\mathbf{2 9 . 7 3 7}$ & $\mathbf{1 5 . 7 8 6}$ & $\mathbf{1 1 . 5 1 7}$ & $\mathbf{1 1 . 3 3 4}$ \\
acquaintances, parents & School & Competitive & Success of & Practical \\
Total \% of Variance & activities & advantages & acceptance & experience \\
Name of factor &
\end{tabular}

The bold variables in one column describe behaviour of a group of students.

Given the results of the factor analyses, it can be stated that the first group of students who decided to study at the selected institution focused their decision primarily on activities and facilities offered by the faculty or university as a whole. It may be concluded that such a group emphasizes 
"school activities". The factor is composed of the variables of university facilities (0.651), option to study abroad (0.858), and offer of supplemental activities (0.857). In comparison, the second factor consists of a group of students who prefer quality references, and therefore place emphasis on the sustainable competitive advantage arising from the quality education. Variables represented include recommendations from peers, acquaintances, parents (0.503), compatibility of the field and subjects with the interests of the student (0.656), and prestige and good name of the school (0.715). The third factor associates students who selected the college based on the chance of acceptance (0.805). This does not, however, consist solely of a negative group, that is students with less aptitude or with lower chances of successfully completing their studies, but overall those who are risk-averse, e.g., have lower confidence or prefer certainty.

On the other hand, one could appeal to the argument that in order to preserve the prestige of the university it is not possible to reduce the barriers to student acceptance. The fourth factor composes a group that prefers the option of combining their studies with work (0.765). Based on this finding, it can be concluded that it is necessary to optimally balance the involvement of students in instruction and the options for working during their studies. However, it is, unfortunately, impossible to give preference to one of the extreme options, as extreme options lead to the trend that students attend classes 1 day per week, reduce the amount of practice (practical applications), and attend solely to obtain general knowledge.

Given the results achieved, it can be summarised that in the current competitive environment, every faculty (university) must create a pleasant and inspiring environment and use informal methods of communication between the faculty and potential and current students, as well as graduates which help to increase the sustainability of quality of education process. The current generations of students, $\mathrm{Y}$ and $\mathrm{Z}$ age categories, give precedence to activities that allow them to achieve their own goals and prefer informal training methods and instructor approaches, including direct inspiring communication, alternative teaching methods, and extracurricular activities associated with the building of successful performance in employment.

\section{Discussion}

It can be summarized that the current situation in higher education is characterized by a large number of different tertiary education institutions, whereas the emphasis on their quality is growing, which is influenced by a wide range of factors that influence students' motivation [31]. In terms of international comparison, the quality of these institutions varies. In the previously mentioned THE World University Rankings, eight colleges and universities in the Czech Republic were included in the top 1000, and the selected university where this study was performed was included in this number.

As part of internal quality ratings, however, institutions of higher learning use a variety of quality assurance methodologies that can better respond to the environment in which the institution is located and thereby to reflect the needs of its interest group [16,32]. Comparing the quality of colleges and universities is therefore a very complicated process, as there are colleges and universities with a very high standard of educational and research activities, and institutions that do not achieve exceptional results in these areas, nonetheless their importance, e.g., for development of education in the specific region, social mission, etc., is not insignificant. Therefore, it is necessary to codify the mission of the individual institutions of higher education [33].

Changes are taking place in students' perceptions of higher education and in terms of obtaining a degree in relation to employment [34]. Collegiate qualifications thus play a diminishing role in today's overburdened postgraduate job market, and, for this reason, students are demanding more added value, which would give them a competitive advantage on the job market, from the institutions of higher education. The respondents participating in this study, however, stated as their main motivation to seek higher education the reasons related to future employment - the possibility of earning more money in the future $(88.7 \%)$, better career growth prospects $(86.7 \%)$ and obtaining a university degree $(85.7 \%)$. Nevertheless, it is evident from the results that students prefer the option of obtaining work 
experience during their studies and gaining knowledge linked to the practical application. It is essential in higher education practice to develop courses that encourage students to think critically, to deepen their ability to transform facts and information into knowledge and to integrate their knowledge with their own personal experience and ideas $[35,36]$.

The perceived quality in collegiate education can be characterised primarily at the level of student motivation and satisfaction with specific university characteristics [10], whereas another research result demonstrate that tangible elements are the most significant dimensions that influence students' perceived satisfaction [19]. This study confirms these conclusions and has likewise determined that the facilities of a university, campus, and general equipment of classrooms have the greatest influence on student satisfaction or the decision to study at the given college or university. More than $75 \%$ of the respondents agreed with this claim.

Institutions of higher education should focus not only on the quality of services provided but also on their image and perception by the wider community [36]. As demonstrated in this study, $66.6 \%$ of students learned about the faculty where they are studying from their community (relatives and acquaintances). The good name of a college or university, therefore, has a significant influence above all on the interest of potential students in attending, whereas the drop in the demographic curve [37] and the increasingly competitive environment create challenges for all institutions of higher education [18]. Therefore, it can be said that the selection of effective methods of communication and marketing activity is becoming an ever more important part of the concept and strategy of higher education $[28,38,39]$. Only nine respondents $(3.1 \%)$ in this study learned about the university through university or faculty presentations given in a school facility. And yet according to Ming, visits by representatives of colleges and universities rank among the extremely important marketing activities that have a significant influence on the choice of a college or university $[40,41]$. As part of their marketing activities oriented towards attracting new students, institutions of higher education should, therefore, evaluate the proportion of their majority students with regard to the secondary school attended, as well as age and other variables, as focal points of their activities. This study confirmed differences in reasons to study at the given school on the basis of age, gender, or type of secondary school attended.

Given the results achieved, it is also necessary to emphasize the necessity to offer students further development and leisure activities, i.e., the development of informal communication and to share experiences between students and teachers, for example by joint visits of an art gallery, a university ball, etc. The faculty management must also realize that a new generation of students is being enrolled at universities and these students cannot be approached without respect, authoritatively; teachers should take the role of mentors, coaches and study guides. Such an approach will enable effective knowledge sharing, increase student motivation to study, increase student retention and reduce the student dropout rate.

\section{Conclusions}

The first part of the study, which focused on the motivation of students to seek higher education and their expectations in relation to quality of instruction, revealed seven significant factors explaining the behaviour of students. The main three factors include a focus on quality personnel providing instruction, building social status, and developing competencies. The results demonstrate that the main reasons students continue in their college studies include the possibility of earning more money in the future $(88.7 \%)$, better career growth prospects $(86.7 \%)$ and obtaining a university degree $(85.7 \%)$. In the second part of the study, four factors were identified combining the behaviour of the sample during the selection of a specific college or university. When choosing a higher education institution, students focused on the activities and facilities of the school, the competitive advantage compared to other educational institutions, success in acceptance, and the option of obtaining practical experience during their studies. It was clear from the study that a strong aspect of this educational institution is primarily its campus, which offers modern classrooms and the option of extracurricular engagement in 
one location. More than three-quarters of respondents identified the facilities of the university as a significant criterion influencing their decision to enrol at this university.

A practical benefit of this article is the presentation of the results of a case study that can aid the further direction of the analysed faculty, as well as other economic faculties, in the recruitment and selection of students for their student programs and help improve the implementation of internal training processes. A limit of this article is the focus solely on the selected economic faculty; nonetheless, the presentation and communication of the case study results are important for effective implementation of processes not only at the selected faculty but also at other faculties with a similar specialization. A further limitation is that students responded to a questionnaire long after enrolment; however, students were surveyed as to their original reasons for applying for higher education, not their actual reasons at the time. It is also the case that the percentage of students who have participated in relation to the total number of students is relatively low. But as the research has been approved by the faculty management, it will be repeated and subsequently evaluated to implement the appropriate marketing strategy.

Author Contributions: All authors contributed equally to this paper.

Funding: This research was funded by the INTERNAL GRANT AGENCY OF THE UNIVERSITY OF LIFE SCIENCES PRAGUE (CIGA), grant number 20171001, "Assessing the quality of instruction in the selected field at the Faculty of Economics and Management of the Czech University of Life Sciences Prague".

Conflicts of Interest: The authors declare no conflict of interest. The funders had no role in the design of the study; in the collection, analyses, or interpretation of data; in the writing of the manuscript, or in the decision to publish the results.

\section{References}

1. Altbach, P.G.; Reisberg, L.; Rumbley, L.E. Tracking a global academic revolution. Chang. Mag. High. Learn. 2010, 42, 30-39. [CrossRef]

2. Czinkota, M.R.; Grossman, D.A.; Javalgi, R.G.; Nugent, N. Foreign market entry mode of service firms: The case of U.S. MBA programs. J. World Bus. 2009, 44, 274-286. [CrossRef]

3. Ghemawat, P. The globalization of business education: Through the lens of semiglobalization. J. Manag. Dev. 2008, 27, 391-414. [CrossRef]

4. Royo-Vela, M.; Hünermund, U. Effects of inbound marketing communications on HEIs' brand equity: The mediating role of the student's decision-making process. An exploratory research. J. Mark. High. Educ. 2016, 26, 143-167. [CrossRef]

5. Leeuwenkamp, K.J.G.; Brinke, D.J.; Kester, L. Assessment quality in tertiary education: An integrative literature review. Stud. Educ. Eval. 2017, 55, 94-116. [CrossRef]

6. Prisacariu, A. New Perspectives of Quality Assurance in European Higher Education. Procedia Soc. Behav. Sci. 2015, 180, 119-126. [CrossRef]

7. Brookes, M.; Becket, N. Quality Management in Higher Education: A Review of International Issues and Practice. Int. J. Qual. Stand. 2008, 1, 85-121.

8. Harvey, L. A history and critique of quality and evaluation in the UK. Qual. Assur. Educ. 2005, 13, $263-276$. [CrossRef]

9. Papanthymou, A.; Darra, M. Quality Management in Higher Education: Review and Perspectives. High. Educ. Stud. 2017, 7, 132-147. [CrossRef]

10. Negricea, C.I.; Edu, T.; Avram, E.M. Establishing Influence of Specific Academic Quality on Student Satisfaction. Procedia Soc. Behav. Sci. 2014, 116, 4430-4435. [CrossRef]

11. Foroudi, P.; Yu, Q.; Gupta, S.; Foroudi, M.M. Enhancing university brand image and reputation through customer value co-creation behaviour. Technol. Forecast. Soc. Chang. 2019, 138, 218-227. [CrossRef]

12. Pavel, A.P. Global University Rankings-A Comparative Analysis. Procedia Econ. Financ. 2015, $26,54-63$. [CrossRef]

13. Furkova, A. Alternative approaches to efficiency evaluation of higher education institutions. J. Effic. Responsib. Educ. Sci. 2013, 6, 167-178. [CrossRef] 
14. Sando, S.; Ferencak, M. Alumni Indicator as a Criterion for Evaluating the Quality of Academic Institutions. Int. J. Ind. Eng. Manag. 2012, 3, 113-119.

15. Olcay, G.A.; Bulu, M. Is measuring the knowledge creation of universities possible?: A review of university rankings. Technol. Forecast. Soc. Chang. 2017, 123, 153-160. [CrossRef]

16. Ivančević, V.; Luković, I. National university rankings based on open data: A case study from Serbia. Procedia Comput. Sci. 2018, 126, 1516-1525. [CrossRef]

17. Ďurišová, M.; Kucharčíková, A.; Tokarčíková, E. Assessment of Higher Education Teaching Outcomes (Quality of Higher Education). Procedia Soc. Behav. Sci. 2015, 174, 2497-2502. [CrossRef]

18. Chui, T.B.; Ahmad, M.S.; Bassim, F.A.; Zaimi, N.A. Evaluation of Service Quality of Private Higher Education Using Service Improvement Matrix. Procedia Soc. Behav. Sci. 2016, 224, 132-140. [CrossRef]

19. El-Hilali, N.; Al-Jaber, S.; Hussein, L. Students' Satisfaction and Achievement and Absorption Capacity in Higher Education. Procedia Soc. Behav. Sci. 2015, 177, 420-427. [CrossRef]

20. Gyure, F.J.; Arnold, G.S. Using 'Relationship Marketing' theory to develop a training model for admissions recruiters. J. Mark. High. Educ. 2001, 10, 35-49. [CrossRef]

21. Kotze, T.G.; Plessis, P.J. Students as 'Co-producers' of education: A proposed model of student socialisation and participation at tertiary institutions. Qual. Assur. Educ. 2003, 11, 186-201. [CrossRef]

22. Moosmayer, D.C.; Siems, F.U. Values education and student satisfaction: German business students' perceptions of universities' value influences. J. Mark. High. Educ. 2012, 22, 257-272. [CrossRef]

23. Mok, K.H.; Jiang, J. Massification of higher education and challenges for graduate employment and social mobility: East Asian experiences and sociological reflections. Int. J. Educ. Dev. 2018, 63, 44-51. [CrossRef]

24. Lyapina, I.; Sotnikova, E.; Lebedeva, O.; Makarova, T.; Skvortsova, N. Smart technologies: Perspectives of usage in higher education. Int. J. Educ. Manag. 2019, 33, 454-461. [CrossRef]

25. Chan, C.K.Y.; Fong, E.T.Y.; Luk, L.Y.Y.; Ho, R. A review of literature on challenges in the development and implementation of generic competencies in higher education curriculum. Int. J. Educ. Dev. 2017, 57, 1-10. [CrossRef]

26. Akareem, H.S.; Hossain, S.S. Determinants of education quality: What makes students' perception different? Open Rev. Educ. Res. 2016, 3, 52-67. [CrossRef]

27. Douglas, J.A.; Douglas, A.; McClelland, R.J.; Davies, J. Understanding student satisfaction and dissatisfaction: An interpretive study in the UK higher education context. Stud. High. Educ. 2015, 40, 329-349. [CrossRef]

28. Rutter, R.; Lettice, F.; Nadeau, J. Brand personality in higher education: Anthropomorphized university marketing communications. J. Mark. High. Educ. 2017, 27, 19-39. [CrossRef]

29. Williams, R.L.; Maktoba, O. How branding process activities impact brand equity within Higher Education Institutions. J. Mark. High. Educ. 2014, 24, 1-10. [CrossRef]

30. Anderson, V. Research Method in Human Resource Management, 2nd ed.; Chartered Institute of Personnel Development: London, UK, 2009.

31. Hitka, M.; Balazova, Z.; Grazulis, V.; Lejskova, P. Differences in Employee Motivation in Selected Countries of CEE (Slovakia, Lithuania and the Czech Republic). Inz. Ekon. Eng. Econ. 2018, 29, 536-547.

32. Poole, S.M.; Levin, M.A.; Elam, K. Getting out of the rankings game: A better way to evaluate higher education institutions for best fit. J. Mark. High. Educ. 2018, 28, 12-31. [CrossRef]

33. Somers, M. Using the process of disruption to find new markets and to develop new marketing programs for management education. J. Mark. High. Educ. 2009, 19, 166-178. [CrossRef]

34. Tomlinson, M. 'The degree is not enough': students' perceptions of the role of higher education credentials for graduate work and employability. Br. J. Sociol. Educ. 2008, 29, 49-61. [CrossRef]

35. Hauke, E. Understanding the world today: The roles of knowledge and knowing in higher education. Teach. High. Educ. 2019, 23, 378-393. [CrossRef]

36. Temizera, L.; Turkyilmaz, A. Implementation of Student Satisfaction Index Model in Higher Education Institutions. Procedia Soc. Behav. Sci. 2012, 46, 3802-3806. [CrossRef]

37. Olcott, D. Back to the UK future: Trends in internationalism and cross-border higher education. Perspect. Policy Pract. High. Educ. 2009, 13, 98-103. [CrossRef]

38. Abbas, S.A. Brand Management of Higher Education Institutions. Int. J. Innov. Appl. Res. 2014, 2, 151-172.

39. Pucciarelli, F.; Kaplan, A. Competition and strategy in higher education: Managing complexity and uncertainty. Bus. Horiz. 2016, 59, 311-320. [CrossRef] 
40. Ming, J.S.K. Institutional Factors Influencing Students' College Choice Decision in Malaysia: A Conceptual Framework. Int. J. Bus. Soc. Sci. 2010, 1, 53-58.

41. Krejcie, R.V.; Morgan, D.W. Determining sample size for research activities. Educ. Psychol. Meas. 1970, 30, 607-610. [CrossRef]

(c)

(C) 2019 by the authors. Licensee MDPI, Basel, Switzerland. This article is an open access article distributed under the terms and conditions of the Creative Commons Attribution (CC BY) license (http://creativecommons.org/licenses/by/4.0/). 